\author{
В.И. Левин
}

\title{
Об одной важной книге по истории логики и философии в Центральной и Восточной Европе
}

Аннотация. В аннотируемой книге воссоздана история развития логики и аналитической философии в странах Центральной и Восточной Европь. Раскрытие данной темы проводится с энциклопедической полнотой. Показано, что вклад учёньх Центральной и Восточной Европь в логику и аналитическую философию не исчерпьвается известньми трудами Венского кружка и Львовско-Вариавской икольь, а намного превьчиат их. Установлено, что многие вьдающиеся уиёные-логики, считающиеся западньми, происходят из Центральной или Восточной Европьлибо находились под сильным влиянием тамочних научных икол. Их отъезд на запад был вызван поисками лучиих условий для работы либо бегством от нацистов.

Работа базируется на анализе всех 38 статей книги, объединённых в 7 глав, а также введения, написанного Эндрю IIlуманом, редактором книги. Статьи весьма информативны и подготовлень 53 авторами из 21 странь Восточной и Центральной Европь (Албания, Беларусь, Босния и Герцеговина, Болгария, Хорватия, Чехия, ГДР, Эстония, Венгрия, Латвия, Литва, Македония, Молдавия, Черногория, Польиа, Румыния, Россия, Сербия, Словакия, Словения, Украина).

Основные выводы: 1) книга "Logic in Central and Eastern Europe" является одной из наиболее важных книг по истории логики и философии науки в мире; 2) книга является своеобразной энииклопедией, в которой изложено всё, что необходимо знать любому ууманитарию об истории логики и билософии в Центральной и Восточной Европе; 3) в книге выявлены причины того, почему советские логико-философские школь не стали ведущими в мире.

Ключевые слова: погика, аналитическая философия, история науки, Центральная Европа, Восточная Европа, имперский период, послеимперский период, научная школа, идеологизация науки, эмиграция.

Abstract. The book under review describes the history of the development of logic and analytical philosophy in Central and Eastern European countries. The topic is being fully and thoroughly covered. In his research Levin demonstrates that the contribution of the scientists of Central and Eastern Europe to the development of logic and analytical philosophy cannot be reduced to famous researches of the Vienna Circle and Lwów-Warsaw school. The author proves that many famous scientists who are thought to come from the West in fact either originated from Central or Eastern Eruope or were under the great influence of the local scientific schools. They emigrated to the West searching for the best working conditions or escaping from the Nazi. The research is based on the analysis of all 38 articles comprising the book and making 7 chapters as well as the introduction written by the editor Andrew Schumann. The book contains very insightful articlse written by 53 researchers from 21 countries of Eastern and Central Europe (Albania, Bulgaria, Bosnia and Herzegovina, Belarus, Czech Republic, Croatia, German Democratic Republic, Estonia, Hungary, Latvia, Lithuania, Macedonia, Moldova, Montenegro, Poland, Rumania, Russia, Serbia, Slovakia, Slovenia, Ukraine). The main conclusions are the following: 1) the book Logic in Central and Eastern Europe' is one of the most important books on the history of logic and philosophy of science in the world; 2) this book is some kind of encyclopaedia which has all the information a humanitarian should know about the history of logic and philosophy in Central and Eastern Europe; 3) the book defines why Soviet logical and philosophical schools have never got to play the leading role in the world.

Keywords: ideologization of science, scientific school, post-empire period, empire period, Eastern Europe, Central Europe, history of science, analytical philosophy, logic, emigration. 


\section{Структура педагогической науки}

\section{1. Введение}

Недавно в США вышла в свет книга, посвященная истории логики и аналитической философии в странах Центральной и Восточной Европы [1]. Книга эта, подготовленная совместно 55 учёными из 21 страны Европы, представляет, по нашему мнению, большой интерес для мирового читателя по нескольким причинам. Прежде всего, это первая в мировой литературе монография, энциклопедически полно раскрывающая данную тему и показывающая, что вклад, внесённый учёными Центральной и Восточной Европы в логику и аналитическую философию, не исчерпывается широко известными трудами Венского кружка и Львовско-Варшавской школы и намного превышает их. Далее, из книги мы узнаем, что многие выдающиеся учёные-логики, которых в мире традиционно считают западными учёными, в молодости испытали сильнейшее влияние восточноили центрально-европейской культуры и науки, которое не оставило их до конца жизни и сильно повлияло на их научное творчество. Наиболее яркий пример - это знаменитый «кембриджский философ» Людвиг Витгенштейн (1889-1951), который ещё в молодости был очарован комментариями Льва Толстого к Евангелию, а в 1930-е гг. сильно симпатизировал коммунизму и даже пытался эмигрировать в СССР, чтобы стать там пролетарием (!). Наконец, эта книга не оставляет сомнений в том, что значительная часть или даже большинство самых известных американских и западноевропейских логиков XX века являются выходцами из Восточной или Центральной Европы (Польша, Россия, Чехословакия и другие страны) и именно там сложились как учёные. Их отъезд на запад был вызван либо поисками лучших условий для научной работы, либо бегством от нацистов. Например, знаменитый американский учёный Курт Гёдель (1906-1978) родился в Брно (Чехословакия), продолжительное время был чехословацким гражданином, позже учился и работал в Вене (Австрия), где в 1931 г. доказал знаменитую теорему о неполноте, а в 1939 г., после присоединения Австрии к нацистской Германии, эмигрировал в США. Другой, не менее знаменитый американский учёный Рудольф Карнап (1891$1970)$ родился в Ронсдорфе (Германия), учился и работал сначала в Иене и Фрайбурге, а с 1926 г. - в
Вене (Австрия). С 1931 по 1935 гг. он жил в Праге (Чехословакия), где преподавал в Немецком университете. Именно в Праге в 1934 г. Карнап написал свою самую знаменитую работу «Логический синтаксис языка» [2]. В 1936 г. Р. Карнап, не дожидаясь захвата Австрии Германией, эмигрировал в США. Десятки других выдающихся, всемирно признанных западных учёных проделали такой же путь. Назовём лишь некоторых из них [3].

Альфред Тарский (1901-1983) родился в Варшаве (Польша), учился и работал в Варшавском университете, с 1934 г. жил и работал в Вене. В 1939 г., накануне войны, эмигрировал в США, где работал в Гарвардском университете и Институте высших исследований в Принстоне, а с 1942 по 1973 гг. - в Калифорнийском университете. А. Тарский был президентом Международного союза истории и философии науки, президентом Ассоциации символической логики, редактором престижного журнала «Journal of Symbolic Logic».

Филипп Франк (1884-1966) родился в Вене (Австрия), учился в Вене и Геттингене. С 1912 г. жил и работал Праге (профессор Немецкого университета, директор института теоретической физики). Один из организаторов Пражского кружка и Венского кружка. В 1939 г. эмигрировал в США, где был профессором Гарвардского университета, директором Института единой науки - продолжателя Венского кружка.

Карл Поппер (1902-1994) родился в Вене, учился в Венском университете, работал учителем в школе. В 1937 г., незадолго до Аншлюса Австрии, Поппер эмигрировал в Новую Зеландию, где преподавал в Кентерберийском университете. С 1946 г. жил в Англии. Преподавал в Лондонской школе экономики и политических наук. Член Лондонского Королевского общества, сэр. Главные труды: «Логика исследования. Теория познания современного естествознания» и «Открытое общество и его враги».

Теперь изложим более подробно содержание книги [1].

\section{2. Развитие науки в имперский период}

Логика и аналитическая философия Центральной и Восточной Европы развивались в XIX-XX вв. в значительной мере независимо в каждой из трёх империй, существовавших там в 


\section{Педагогика и просвещение 3(19) • 2015}

указанное время: Российской, Австро-Венгерской и Османской (Турецкой).

Российская империя (1721-1917) была крупнейшим по территории государством мира своего времени и третьим по населению (после Китая и Великобритании). Она стала христианской преемницей Монгольской империи - крупнейшей империи в истории мира, унаследовавшей у монголов политический строй с твёрдым централизмом и абсолютизмом. Несмотря на жёсткое политическое устройство, наука в Российской империи, включая логику, развивалась достаточно свободно и успешно, благодаря императору Петру I, перенявшему и внедрившему в российскую практику научные традиции Западной Европы (Голландии и Германии). Логические исследования в стране выполнялись, в основном, в Казани (Казанский университет), Одессе (Новороссийский университет) и Киеве (Киево-Могилянская академия). Так, казанский профессор Платон Порецкий (1846-1907) был одним из самых известных российских основателей современной логики, одесский профессор Евгений Буницкий (1874-1952) - известным специалистом по алгебре логики, другой одесский профессор Самуил Шатуновский - крупным специалистом по логике и основаниям математики, а киевский профессор Иван Скворцов (1799-1863) - видным учёным в области классификации логик. Видными российскими учёными-логиками были Виктор Бобынин (1849-1919) и Иван Слешинский (1854-1931). Российские учебники по логике были хорошего качества и лучшие из них переводились на иностранные языки. Особой популярностью пользовался учебник «Логика как часть теории познания» видного русского философа Александра Введенского (1856-1925), он был издан в Санкт-Петербурге в 1912 г.

Государственной религией Российской империи было православие, а государственным языком - русский. Именно на нём велась наибольшая часть научных исследований и публикаций по логике. Сказанное не означает, что в неправославных регионах Российской империи с другими языками не проводились логические исследования. В первую очередь, это относится к католической Польше, где в начале XX в. возникла широко известная Львовско-Варшавская школа логики и философии. Основатель этой школы профессор
Львовского университета Казимир Твардовский и её участники писали свои работы, как правило, на польском языке, иногда - на немецком.

Австро-Венгерская империя (1867-1918) была второй по величине (территории и населению) страной в Европе после Российской империи. По этнической культуре и населению эта страна была очень разнообразна и включала исповедовавших католичество австрийцев и немцев с центром Вена и венгров с центром Будапешт, православных славян с центрами в Чехословакии и Сербии и румын с центром Бухарест. Однако приоритет однозначно отдавался немецкой культуре и немецкому языку. В частности, бесспорным приоритетом пользовались немецкая философия и логика. Здешние философы находились под сильным влиянием идей Иммануила Канта. Что касается логики, то здесь доминировали немецкие учёные, рассматривавшие логику как введение в философию и сокращавшие её содержание до одной психологии. Наиболее известными учебниками были «Элементы философии» Фредерика Баумейстера (1708-1785) и «Философская пропедевтика» Джозефа Бека (1803-1883). Австрийские учебники по философии и логике переводились на национальные языки этнических меньшинств Австро-Венгрии.

Серьёзные исследования по логике и аналитической философии появились в Австро-Венгрии в начале XX в. Эти исследования были связаны преимущественно с возникновением научной школы, получившей название «Венский кружок» и уже в середине 1930-х гг. ставшей всемирно известной. Эта школа дала миру много выдающихся учёных-логиков и философов. Некоторые были уже упомянуты выше: Л. Витгенштейн, К. Гёдель, Р. Карнап, А. Тарский и др.

Османская (турецкая) империя (1299-1923) длительное время являлась центром сильного культурного влияния в Центральной Европе. В период наибольшего расцвета (XVI и XVII вв.) эта империя простиралась на три континента и включала в себя большую часть юга Центральной Европы (Греция, Сербия, Черногория, Хорватия, Болгария, Македония, Румыния, Албания, Босния и Герцеговина), Западную Азию (современная Турция) и северную Африку (современная Ливия). Повсеместно в империи приоритет отдавался мусульманскому турецкому этносу и турецкому 


\section{Структура педагогической науки}

языку. Турки легко ассимилировали другие этнические группы, включая славян. Эта ассимиляция сопровождалась исламизацией. Вместе с тем, с начала XIX в. территории империи, населенные славянами, греками и хорватами, непрестанно боролись за национальную независимость, и эта борьба успешно завершилась лишь во второй половине XIX в. Поэтому формирование философских и логических традиций в православных Греции, Сербии, Черногории, Болгарии и католической Хорватии произошло достаточно поздно. Так, первое настоящее философско-теологическое произведение в Черногории было напечатано в Белграде только в 1845 г. Оно называлось «Луч микромира» и принадлежало Петру Пйтровичу (1813-1851). Аналогично, в Болгарии первое руководство по логике было написано лишь в 1864 г. Оно было написано Василем Х. Стояновым-Бероном, называлось «Логика: первый опыт изложения по-болгарски» и было издано в Вене. Немного раньше появились публикации научных работ по логике и философии в Хорватии. Например, там уже в 1847 г. Ватрослав Бертич разработал элементарный логико-алгебраический язык «мыслей и понятий», где фигурировали переменные, константы, признак равенства выражений и закон замены.

На территории православной Румынии, присоединенной к Османской империи в XVII в., философские и логические традиции начали складываться тогдаже, при решающем участии греческих учёных-иммигрантов. Эти учёные создали в стране научные центры, в которых философия и логика преподавались в духе классической греческой философии Аристотеля, на греческом и латинском языках. И лишь в XIX в. преподавание было переведено на румынский.

Еще более удивительным образом сложились философские и логические традиции на другой подвластной Османской империи территории - в Боснии и Герцеговине. Эти традиции были созданы под решающим влиянием ислама в его турецкой версии. При этом обучение в многочисленных медресе (религиозных училищах) проводилось последовательно на трех уровнях. На 1-м уровне изучались грамматика и синтаксис арабского языка, арифметика, геометрия, логика, риторика и апологетика. На 2-м уровне изучались те же самые предметы, но значительно более широко.
На 3-м, самом высоком уровне, изучались законы шариата, толкования Корана и основы исламской традиции. Наиболее авторитетным учебником по логике была написанная на арабском языке книга «Основы логики», состоявшая из 4 частей: 1) рассуждения, 2) введение в логику, 3) метафоры в арабском языке, 4) задания по логике. Мусульмане Боснии и Герцеговины продолжали образование в престижных школах Стамбула, Багдада, Дамаска. Работы по логике в Боснии и Герцеговине были написаны на арабском языке. Их содержание составляли, главным образом, комментарии по аристотелевой логике арабских логиков Аль Фараби, Аль Кинди, Ибн Сина, Ибн Рузда.

\section{3. Послеимперский период}

После краха Российской (1917), АвстроВенгерской (1918) и Османской (турецкой) (1923) империй возникли новые государства, учёные которых внесли большой вклад в развитие логики и аналитической философии.

CССP, по конституции социалистическое государство, образовалось после распада Российской империи и просуществовалос 1922 по 1991 гг. Это был союз 15 республик (Россия, Азербайджан, Армения, Белоруссия, Грузия, Казахстан, Кыргызстан, Латвия, Литва, Молдова, Таджикистан, Туркмения, Узбекистан, Украина, Эстония). После аннексий балтийских государств, Восточной Польши, Бессарабии и Южной Финляндии во время II мировой войны границы СССР примерно совпадали с границами Российской империи 1917 г. После войны Советский Союз реально управлял всей Восточной и почти всей Центральной Европой. Политика гласности М.С. Горбачева (1985), после десятилетий тотальной цензуры, привела к социальному хаосу, затронувшему политическую систему государства, и к его последующему развалу. В 1991 г. все республики, составлявшие СССР, стали независимыми странами.

Югославия как независимое государство (королевство) образовалась в 1918 г. из недавно сформированных на обломках АвстроВенгрии государств - Сербии, Словении и Хорватии. Королем Югославии стал Александр Кара Джорджевич. В апреле 1941 г. страна была оккупирована фашистской Германией. В про- 


\section{Педагогика и просвещение 3(19) • 2015}

цессе борьбы с оккупацией в 1943 г. была создана Демократическая Федеральная Югославия (c 1963 г. - Социалистическая Федеративная Республика Югославия - СФРЮ). Это была федерация, включавшая Сербию, Хорватию, Черногорию, Македонию, Словению, Боснию и Герцеговину. В 1991 г. после югославских войн СФРЮ разделилась на шесть составлявших её государств, ставших независимыми.

Чехословакия как независимое государство (республика) была сформирована в 1918 г. после краха Австро-Венгрии. Во главе её встал выдающийся политик Томаш Масарик. В результате Мюнхенского соглашения 1938 г. страна была захвачена фашистской Германией. Это вызвало в стране недовольство политикой Запада и сближение с СССР. На выборах в парламент в 1946 г. коммунисты получили $38 \%$ голосов (большинство) и образовали просоветскую Чехословацкую Социалистическую Республику. В 1989 г. в результате бескровной революции Чехословакия вышла из советского блока и образовала независимую Чехословацкую Республику. В 1993 г. государство мирно разделилось на Чешскую республику и Словацкую республику.

Венгрия как независимое государство впервые образовалась после краха Австро-Венгрии в 1919 г. под названием Венгерская советская республика. Однако её коммунистический режим - первый режим такого рода, установленный в Европе после Октябрьской революции 1917 г. в России - продержался недолго (с 21 марта до 6 августа 1919 г.). После развала Венгерской советской республики, чему помогла армия соседней Румынии, возникло новое государство - Королевство Венгрия. Во время II Мировой войны Венгрия воевала на стороне фашистской Германии против СССР. После освобождения страны Советской Армией была создана просоветская коммунистическая Венгерская Народная Республика. В 1989 г. в стране прошла бархатная революция, приведшая её к выходу из советского блока и созданию независимой Республики Венгрия.

Румыния впервые получила независимость от Османской (Турецкой) империи ещё в 1878 г. Во время Второй балканской войны Румыния вместе с Сербией, Черногорией, Грецией и Турцией воевала против Болгарии и получила по Бухарестскому мирному договору 1913 г. Южную Добруджу. Румыния воевала во II Мировой войне на стороне фашистской Германии против Советского Союза. После освобождения страны Советской Армией коммунисты вынудили короля Румынии Михая I отказаться от трона и уехать за границу, а сами провозгласили просоветскую Румынскую Народную Республику. В 1989 г. в стране произошла кровавая революция, в результате которой её коммунистический многолетний правитель Николае Чаушеску был отстранён от власти и расстрелян, а государство преобразовано в независимую Республику Румынию.

Албания получила номинальную независимость от Османской (Турецкой) империи в 1912 г. Однако фактически она стала протекторатом Австро-Венгрии и Италии. Создание нового государства не устраивало Грецию, Сербию и Черногорию, желавших разделить албанские территории между собой. Албания после II Мировой войны стала социалистической страной, примкнула к СССР и входила в течение 15 лет в число «стран народной демократии». Однако в 1969 г. она покинула «социалистический лагерь» из-за несогласия с начавшейся там десталинизацией. В качестве альтернативы Албания выбрала сильный политический союз с коммунистическим маоцзедуновским Китаем. В 1989 г. Албанская Народная Республика, как и остальные коммунистические режимы в Восточной Европе, начала разрушаться. В результате была создана независимая Республика Албания.

Польша с 1795 г. была разделена между Австрией, Пруссией и Россией. Свою независимость страна восстановила только в 1918 г., после Октябрьской революции 1917 г. в России, развала Австро-Венгрии (1918) и поражения Германии в I Мировой войне (1918). Была провозглашена Вторая Польская Республика. В 1939 г. Польша была снова разделена - на этот раз между фашистской Германией и СССР. После Второй Мировой войны стараниями СССР и польских коммунистов была образована социалистическая Польская Народная Республика, входившая в советский блок. После революции 1989 г. коммунистическое правление было свергнуто и была построена Третья Польская республика, получившая название Республика Польша. 


\section{Структура педагогической науки}

Болгария в результате восстания против Османской империи (1876), Русско-Османской войны в защиту болгар (1877-1878) и СербскоБолгарской войны (1885) стала большим государством - вассалом Российской империи, получив название Болгарское княжество. В 1908 г. страна объявила себя полностью независимой, с названием Королевство Болгария. Во время Второй Мировой войны Болгария была оккупирована фашистской Германией, однако какого-либо участия в войне не принимала. После войны усилиями болгарских коммунистов, при сильной поддержке Советского Союза, была построена Народная Республика Болгария, которая просуществовала до 1989 г. и входила в состав советского блока. В 1989 г. в результате произошедшей революции коммунистическое правительство страны, как и везде в Восточной Европе, было свергнуто. Возникло новое государство - Республика Болгария, которое постепенно сменило свою просоветскую ориентацию страны на западную.

Германская Демократическая Республика (ГДР) была создана на востоке освобожденной Германии в 1949 г. силами немецких коммунистов, при участии СССР. В состав этого государства вошли шесть земель Германии, составлявших с 1945 г. советскую зону оккупации страны. Жесткие методы управления коммунистических властей ГДР вызвали массовое недовольство населения страны и бегство миллионов людей на Запад. В конце 1980-х гг. в стране вспыхнуло антикоммунистическое восстание, охватившее практически все слои жителей. Государственные и партийные органы власти были сметены и государство с названием ГДР в считанные дни перестало существовать. В 1990 г. вся его территория вошла в состав Федеративной Республики Германия, созданной в 1949 г. на базе американской, английской и французской зон оккупации страны. Тем самым была решена проблема воссоединения Германии, расколотой в результате Второй Мировой войны.

\section{4. Развитие науки в послеимперский период}

Просоветские коммунистические государства, созданные в Восточной и Центральной Европе после Второй Мировой войны, при наличии на их территории Советской Армии, находились под контролем СССР. В связи с этим развитие культуры, науки и образования в этих странах сильно зависело от направления их развития в СССР. Но последнее характеризовалось полным идеологическим контролем советского государства над любыми видами творческой деятельности. Считалось, что истинной идеологической основой любого творчества должен быть диалектический материализм - философская теория, развитая в рамках традиции марксизма-ленинизма. Философское значение указанной теории было ничтожным, поскольку она являлась слишком общей и в результате этого почти ничего не касалась. С её помощью можно было объяснить любое явление: естественное, социальное, интеллектуальное, но ничего нельзя было предсказать. Кроме философской, у диалектического материализма была и политическая составляющая - победа коммунистической революции во всем мире, с ликвидацией частной собственности и созданием общества пролетариев с равным уровнем жизни для всех. Советское искусство диалектический материализм призывал создавать образы уверенных в победе героев, строителей коммунизма.

В советской науке диалектический материализм проталкивался как принудительный философский контекст любого научного рассуждения. Нередко этот контекст был важнее собственно содержания научного рассуждения. Например, псевдонаучные идеи Д.Т. Лысенко были гораздо более созвучны марксистско-ленинскому контексту, чем идеи генетики. Поэтому её идеи генетики клеймились как буржуазные, ведущие советские генетики были репрессированы, а Лысенко стал контролировать развитие всей биологии в СССР. Доминирование догматического диалектического материализма во всех сферах жизни мешало открытой социальной деятельности в стране и вело к отсутствию гласности, устранению конкурирующих моделей поведения и т.д. Но большая наука - это разновидность социальной деятельности. Так что в советском обществе сложилось жестко безальтернативное отношение к получению научного продукта, а управление научной деятельностью проводилось с помощью иерархических административно-командных методов. Иерархическая организация советской науки была встроена в иерархическую организацию советской плановой 


\section{Педагогика и просвещение 3(19) • 2015}

экономики. Здесь финансирование всех научных исследований осуществлялось государством. Дефекты такой системы организации науки очевидны и они были известны самим советским учёным. Так, в 1988 г. выдающийся советский учёный в области космонавтики академик Б. Раушенбах писал «Чтобы развиваться, необходимо позволить людям работать. Однако у нас наука устроена таким способом, при котором работа менее важна, чем бумажные отчёты о работе. В такой структуре талант испытывает трудности, но бездельник чувствует себя очень хорошо. Наша структура запрограммирована на освобождение учёных от обязательств активной работы. Планирование науки происходит у нас как планирование проблемы карандашей».

Несмотря на указанные дефекты в организации советской науки, у неё были несомненные, международно признанные успехи в области математики, физики и техники. Это можно объяснить тем, что из-за давления на учёных сверху и полной изоляции советской науки конкуренция между различными исследовательскими группами была чрезвычайно высока. В такой социальной структуре образцом советского учёного стал скромный, нетребовательный и самоотверженный человек, занимающийся наукой только ради науки. Таким человеком являлся, например, В.И. Шестаков, один из основателей кибернетики, открывший в 1930-е гг. (наряду с американцем К.Э. Шенноном и японцем А. Накашимой) возможность логического моделирования релейных схем. У В.И. Шестакова было много и других интересных результатов. Однако вся его жизнь прошла в бедности. Следы подобного отношения советских учёных к своей науке сохранились и до наших дней. Они видны, например, в «странном» поведении выдающегося современного российского математика Г.И. Перельмана. Последний внёс значительный вклад в риманову геометрию, геометрическую топологию и доказал знаменитуюг гипотезу Анри Пуанкаре (1904) - одну из математических проблем тысячелетия. Но он отказался от всех присуждённых ему наград, хотя в формулировках наград говорилось, что они присуждаются Перельману за «Его вклад в геометрию и его революционную способность проникновения в суть аналитической и геометрической структуры».
Созданные в Центральной и Восточной Европе после Второй Мировой войны просоветские государства - Югославия, Чехословакия, Венгрия, Румыния, Польша, Албания, Болгария, Германская Демократическая Республика - приняли идеологическую систему Советского Союза. Соответственно этому был принят диалектический материализм как принудительный философский контекст любого научного рассуждения, советская модель организации и управления наукой и советский образец учёного. Русский язык стал одним из международных научных языков, наряду с английским, а Москва - одним из самых влиятельных международных научных центров. Однако эта ситуация была во многом искусственной: не только учёные СССР, но и учёные стран Варшавского договора могли знакомиться с последними результатами западных учёных не на языках оригинала, а лишь на российских переводах. Диалектический материализм был крайне враждебен к аналитической философии, особенно к позитивизму (неопозитивизму), развивавшемуся учёными знаменитого Венского кружка. Причина такого отношения заключалась в технологичности аналитической философии - положительном свойстве, полностью отсутствовавшем в спекулятивном диалектическом материализме. Внедрение новой идеологии в философских сообществах государств Восточного блока, в отличие от СССР, наталкивалось на серьёзные трудности, поскольку во многих странах, таких как Венгрия, Польша, Хорватия, Чехословакия, традиции аналитической философии закрепились уже в период между двумя Мировыми войнами. Благодаря этому некоторые центры аналитической философии в указанных странах удалось сохранить. Например, венгерский центр, возглавлявшийся И. Лакатосом, учеником К. Поппера, внесшим заметный вклад в философию науки. Однако Москва экспортировала в страны коммунистического Восточного блока не только схоластический диалектический материализм. В послевоенные годы благодаря стараниям советского учёного-просветителя С.А. Яновской удалось защитить науку логику и не допустить, чтобы она разделила судьбу советской генетики. В результате в течение короткого времени советские математики восприняли с 


\section{Структура педагогической науки}

Запада по осуществленным Яновской переводам основные научные результаты в области теории алгоритмов, теории вычислимости, неклассической логике (интуиционистской, конструктивной, многозначной) и т.д. Созданные таким путём традиции математической логики СССР экспортировал в государства Восточного блока. Кроме того, многие видные впоследствии учёные-логики этих стран получили образование в Москве. Это Д. Скордев (Болгария), ставший известным специалистом по теории рекурсии, Г. Гаргов (Болгария), специалист по интуиционистской логике, ученик советского математика А. Драгалина (1941-1988). Основатель советской школы конструктивной математики и логики А.А. Марков (1903-1979) стал в указанный период крупнейшим логиком в странах Советского блока и руководителем одной из наиболее успешных логико-математических школ в мире. В целом же советская логико-математическая школа не была гегемоном в социалистическом пространстве - достойным конкурентом ей была польская логико-математическая школа, сложившаяся ещё в 1930-е г. и тесно сотрудничавшая после Второй Мировой войны с логиками Болгарии и ГдР.

Как уже говорилось выше, большинство исследований в рамках диалектического материализма (особенно в СССР) было псевдонаучным. Однако даже в рамках марксистской философии были получены некоторые интересные результаты в области логики и философии науки. Так, Э. Ильенков (1924-1979) предложил оригинальную версию диалектической логики, которую можно рассматривать как современную версию неординарной логики Канта или спекулятивной логики Гегеля. Данная логика анализирует процесс формирования знаний и не игнорирует содержание рассуждений. В Германской Демократической Республике сложилась оригинальная традиция социалистической философии науки, в которой использовались идеи экономической кибернетики. В рамках этого подхода было получено много новых интересных результатов.

\section{5. Некоторые общие выводы}

По мнению редактора книги [1], основной вклад данной книги в литературу по логике и философии состоит в следующем.
1. Изложенный в книге материал поясняет социально-исторический контекст развития логики, аналитической философии и философии науки в Центральной и Восточной Европе в XIX-XX вв., показывает масштаб политических и социальных потрясений в указанных областях в течение последних 200 лет: движения за национальную независимость, волнения в империях, Первой Мировой войны, короткого периода независимости между войнами, Второй Мировой войны, социалистической системы и Восточного блока и, наконец, периода новой независимости с 1990-х гг. Политическая и социальная нестабильность в Центральной и Восточной Европе прервала развитие логико-философских традиций и помешала созданию больших научных школ в этих областях. Несмотря на это, к концу ХХ столетия учёными Центральной и Восточной Европы были получены выдающиеся результаты в логике и информатике. Это проявилось, в частност и, в том, что начальное (1940-е гг.) и вполне успешное развитие компьютерных технологий в Советском Союзе произошло совершенно независимо и параллельно с Западом, с задержкой всего на 1-3 года. Так, первый западный компьютер с надёжной программой «Манчестер-1» был сконструирован англичанами Ф.К. Уильямсом и Т. Килберном в 1948 г., а первый аналогичный советский компьютер МЭСМ создан академиком С. Лебедевым в 1951 г. Что касается серийно выпускаемых машин, то первый западный компьютер IBM-701 был создан в 1951 г., а первые аналогичные советские компьютеры БЭСМ-1 и «Стрела»- в 1953 г. В те же годы советский математик А.А. Ляпунов (1911-1973) предложил одну из первых терминологий языков программирования. Специалисты из СССР, Болгарии, Венгрии, Польши, Чехословакии и ГДР участвовали в создании ЭВМ третьего поколения (1968-1973), были реально изготовлены компьютеры Мир-31, Мир-32, Наири-34.

2. Однако в целом развитие компьютерных технологий в СССР и государствах-членах Восточного блока всё больше отставало от соответствующих аналогов на Западе. Это было вызвано, во-первых, централизованным управлением наукой в этих странах, что мешало реализации научных идей в создании коммерчески выгодных машин, и, во-вторых, нетехнологичностью 


\section{Педагогика и просвещение 3(19) • 2015}

советских гуманитарных наук, вызванной их уходом от аналитической философии, философской логики, критического мышления и других ветвей «работающей» (технологической) философии из-за идеологических соображений. Здесь, возможно были и иные причины. Так, выдающийся советский программист А.Д. Закревский, участвовавший в создании первых компьютеров в СССР, разработчик первого советского языка программирования ЛЯПАС, сообщил в интервью проф. А.Н. Шуману, что в 1970-х гг. лидеры СССР приняли решение останавливать все оригинальные разработки в области компьютерной техники и лишь копировать западные образцы, в основном, фирмы IBM. Решение властей страны было очень странным, оно ускорило отставание СССР в компьютерных технологиях. По мнению Закревского, это решение, вероятно, было связано с большими взятками, полученными высокопоставленными советскими чиновниками от IBM. После того как СССР прекратил гонку за создание лучших компьютеров, IBM стала общемировым лидером в этой области. Вслед за этим огромное число специалистов по компьютерным технологиям из СССР и социалистических стран эмигрировало на Запад, что сделало дальнейшее продвижение указанных стран в компьютерных технологиях вообще невозможным.

3. Логико-философы - представители Венского круга и Львовско-Варшавской школы - получили свои первые существенные научные результаты в период между Первой и Второй Мировыми войнами. Тогда же большинство их эмигрировало на Запад (в основном, в США), где они удачно присоединились к академическому сообществу и стали всемирно известными. Остальные учёные, работавшие в области логики, аналитической философии и философии науки в Центральной и Восточной Европе, были менее удачливы. Их первые существенные научные результаты были получены после Второй Мировой войны, когда уже началась холодная война и изоляция стран Восточного блока, в результате чего свободный обмен идеями и результатами стал невозможен. К тому же эти учёные испытывали давление с обеих сторон: от руководства своих стран, стоящего на страже диалектического материализма и коммунистической идеологии, и от западного академического сообщества, имевшего традиционные предубеждения против стран Центральной и Восточной Европы. В результате в Центрально- и Восточноевропейских странах после Второй Мировой войны не сложились всемирно известные логические и аналитико-философские школы, хотя там имелись все потенциальные предпосылки для этого. Восстановление логических и аналитико-философских традиций в этих странах началось лишь в 1989-1991 гг., после приобретения ими государственной независимости, в результате начавшегося развала СССР. На этом пути были достигнуты значительные научные результаты. Образованы хорошо развитые логико-философские сообщества, издаётся множество журналов по логике и аналитической философии. Ведущее положение сейчас здесь занимают научные школы Венгрии, Польши, Сербии, Словении, Хорватии, Чехии. Догоняют их молодые школы других стран. Здесь можно назвать, например, Латвию и Литву. В наиболее тяжелом положении находятся логические и аналитико-философские сообщества России, Украины и Белоруссии, которые по политическим причинам оказались изолированы от процессов интеграции Европы. В результате они постепенно исчезают, теряя те позиции, которые они имели во времена СССР.

\section{6. Заключение}

По нашему мнению, книга [1] является одной из наиболее важных работ по истории логики и философии науки в мире за последние годы. Из книги читатель узнаёт подробно, как складывались и развивались соответствующие научные школы в Центральной и Восточной Европе и какое большое влияние они оказали на логические и философские исследования в мире. Содержание книги уникально: в ней достаточно подробно изложены история возникновения и развития науки логики, аналитической философии и философии науки в Центральной и Восточной Европе (отдельно по каждой стране), содержание всех полученных в этих областях важнейших результатов, влияние проведенных в Центральной и Восточной Европе логико-философских исследований на мировую науку. По существу, читатель получает энциклопедическое издание большого объёма (730 стр.!), в котором в свободной форме 


\section{Структура педагогической науки}

изложено практ ически всё, что необходимо знать любому продвинутому гуманитарию ичто может оказаться полезным любознательным людям любых специальностей. Этого удалось достичь благодаря участию в проекте большого числа (55)! высококвалифицированных специалистов из 21 Центрально- и Восточноевропейской страны, которых привлек к работе над книгой её редактор профессор Андрей Шуман.

Особое значение имеет книга для русского читателя, который с её помощью получает возможность понять, почему советские (российские) логико-философские школы не стали признанными в мире ведущими школами, хотя для этого были реальные предпосылки. Причиной этому, как показано в книге, была ущербная централизованная организация управления наукой в нашей стране, а также её чрезмерная идеологизация.

В книге имеются некоторые недостатки. Главный из них: примитивное и нелогичное объяснение международно признанных успехов советской математики, физики и техники, несмотря на организационно-идеологическое давление властей на учёных. В книге эти успехи объясняются тем, что в условиях полной изоляции советской науки конкурентоспособность различных групп исследователей чрезвычайно возросла, а власти распропагандировали образец советского учёного как скромного, нетребовательного человека, готового жить в бедности, лишь бы заниматься любимой наукой. На самом же деле причина успехов советской науки в указанных областях состояла в том, что советская власть хорошо понимала значение науки для экономики и обороноспособности страны и поэтому оказывала сильную материальную и моральную поддержку науке и учёным - гораздо большую, чем современное российское государство. Взамен советская власть требовала от учёных только одного - не вмешиваться в политику. Но серьёзный, успешно работающий учёный обычно не имеет ни времени, ни интереса заниматься политикой. Поэтому описанная модель взаимодействия между советской властью и советскими учёными, хотя и была предложена властью, устраивала обе стороны. Другой недостаток книги - большое различие в объёме материала и характере его изложения между различными главами, принадлежащими различным авторам. Такое же различие наблюдается в приведённых биографических данных об авторах. Затрудняет пользование книгой отсутствие в ней предметного и именного указателей. Претензии имеются и к издательству University Press of America, выпустившему рассматриваемую нами книгу: оно оформило её как единоличную монографию её редактора А. Шумана, в то время как она является коллективной монографией 55 авторов, содержащей 7 глав и 38 параграфов, проф. А. Шуман же написал к ней только предисловие.

Монография [1] будет полезным источником сведений по истории логики, аналитической философии и философии науки для учёных всех стран. В России подобных книг сегодня нет. Поэтому данную книгу было бы весьма целесообразно перевести на русский язык.

\section{Список литературы:}

1. Logic in Central and Eastern Europe. N.Y.: University Press of America, 2013. 730 p.

2. Carnap Rudolf. Der logische Syntax der Sprache. Vien, 1934.

3. Журнал «Erkentis» («Познание»). Избранное. М.: Издательский дом «Территория будущего», Идея-Пресс, 2007. 472 с.

\section{References (transliteration):}

1. Logic in Central and Eastern Europe. N.Y.: University Press of America, 2013. 730 p.

2. Carnap Rudolf. Der logische Syntax der Sprache. Vien, 1934.

3. Zhurnal «Erkentis» («Poznanie»). Izbrannoe. M.: Izdatel'skii dom «Territoriya budushchego», IdeyaPress, 2007. 472 s. 